IRA-International Journal of Management \&

Social Sciences

ISSN 2455-2267; Vol.13, Issue 02 (November, 2018)

Pg. no. 23-31.

Institute of Research Advances

http://research-advances.org/index.php/RAJMSS

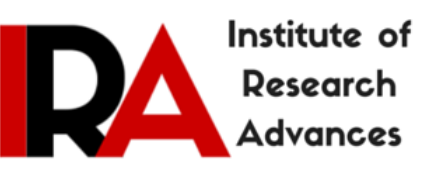

\title{
Recent Trends in the Attitude towards Economic Independence of Women
}

\author{
Dr. Suneetha. V. \\ Associate Professor, Department of Postgraduate Studies in Sociology, Government Arts, \\ Commerce \& Postgraduate College (Autonomous), Hassan- 573201, Karnataka, INDIA.
}

Type of Review: Peer Reviewed.

DOl: http://dx.doi.org/10.21013/jmss.v13.n2.p1

\section{How to cite this paper:}

Suneetha, V. (2018). Recent Trends in the Attitude towards Economic Independence of Women. IRA-International Journal of Management \& Social Sciences (ISSN 2455-2267), 13(2), 2331. doi:http://dx.doi.org/10.21013/jmss.v13.n2.p1

(C) Institute of Research Advances.

(cc) BY-No

This work is licensed under a Creative Commons Attribution-Non Commercial 4.0 International License subject to proper citation to the publication source of the work.

Disclaimer: The scholarly papers as reviewed and published by the Institute of Research Advances (IRA) are the views and opinions of their respective authors and are not the views or opinions of the IRA. The IRA disclaims of any harm or loss caused due to the published content to any party.

Institute of Research Advances is an institutional publisher member of Publishers International Linking Association Inc. (PILA-CrossRef), USA. The institute is an institutional signatory to the Budapest Open Access Initiative. Hungary advocating the open access of scientific and scholarly knowledge. The Institute is a registered content provider under Open Access Initiative Protocol for Metadata Harvesting (OAI-PMH).

The journal is indexed \& included in WorldCat Discovery Service (USA), CrossRef Metadata Search (USA), WorldCat (USA), OCLC (USA), Open J-Gate (India), EZB (Germany) Scilit (Switzerland), Airiti (China), Bielefeld Academic Search Engine (BASE) of Bielefeld University, Germany, PKP Index of Simon Fraser University, Canada. 


\begin{abstract}
To eliminate all types of discrimination against women and establish gender equality major strategies such as social empowerment, economic empowerment and gender justice were implemented. Achieving Economic Independence for women has been at the core of vision for gender equality across the globe. India is a male dominant society and traditionally jobs were meant for men. But as the international concern with gender relations in development has strengthened the affirmation that equality in the status of men and women is fundamental to every society, modern Indian Society has witnessed a gradual change in the status of women. The emergence of the new economic environment, the establishment of the new political system and the spread of modern education and ideologies among the people, found expression in the liberation of the Indian women from the traditional forms of social subordination and suppression from which they suffered for centuries. As of nowadays, no community cannot deny the role women have played in the progress of a community, changes have taken place in the attitudes of the people towards their women. Economic independence was considered as one of the powerful routes to economic empowerment and thereby to gender equality. In modern Indian society notion of women's participation in employment for their empowerment is widely identified. In this direction this research article has tried to trace the recent trends in the attitudes of Indians towards economic independence of the women. This article tried to give answer for some questions like- whether community as a whole had favorable attitude towards economic independence of women? Is really women empowerment is possible? Is there actually people felt the necessity of it? etc.
\end{abstract}

Key Words: Economic Independence, Economic Empowerment, Women, Gender Equality

\title{
Introduction
}

Women are a significant part of all-round development of society and economy. The development of women as the human resource of the country has been recognized as a crucial factor in the progress of society and economic development. In the pre-British Indian society, except perhaps in the early periods of the Vedic times, woman was assigned a position subordinate to man (A.R. Desai, 1948, p. 273). It is believed that during the Vedic period the position of woman was generally equal to that of the man. During the Vedic period, when civilization was simple, life was lived in agricultural communities and wealth consisted of crops and cattle, woman was comparatively free and her place in the community was naturally determined by her ability to share the work of that community. The trend of decline in the status of women was started in the post-Vedic period. It was generally opined that restrictions began to be imposed, caste rigidities emerged, and various evil practices which affected adversely the women, crept into the fabric of Indian Social System during the medieval times.

According to P.H. Prabhu (1940, p261) recent cross-cultural studies by Anthropologists like Margaret Mead seem to indicate that personality and character differences are in general basically influenced by the cultural norms of the society in which an individual is born and bred. Even the character and temperament traits associated with 'maleness' and 'femaleness' are profoundly influenced and are the resultant of the peculiarities of the culture to which its men and women belong. On this basis, it can be said that the status of woman in Indian society is determined by the traditions, beliefs, and attitudes of the community. However modern Indian Society has witnessed a gradual change in the status of women. As noted by A.R Desai (1948) the general national and democratic awakening, which took place in India as a consequence of the emergence of the new economic environment, the establishment of the new political system and the spread of modern western education and ideologies among the people, found expression in the movement for the liberation of the Indian women from the medieval forms of social subordination and suppression from which they suffered for countless centuries. A milestone in the international efforts to empower women is adoption of 'Elimination of All Forms of Discriminations against women on December' $18^{\text {th }} 1979$, by the general assembly of the UNO. This states that (CEDAW,1979) “......the full and complete development of a country, the welfare of the world and the cause of peace require the maximum participation of women on equal terms with men in all fields". In 1995, the Fourth World Conference On Women in Beijing expanded the focus and included in its action plan, various issues related to woman like human rights and women, women and health, education and training of women, women and economy, women in power and decision making, institutional mechanism for empowerment, the concern of the girl child etc. The United Nations Development Programme (UNDP) in its report (1995) clearly stated that unless women are engendered, they will be 
endangered. Empowerment of women is given special importance by all development agencies and it is the third of Millennium Development Goal (MDG), 2015. In India also 'Empowerment of women' is an important approach adopted for development of society. Achieving economic independence for women has been at the core of vision for gender equality across the globe.

Economic Independence for Women refers to expanding the capacity of women to make genuine choices of their lives about their lives through full and equal participation in all spheres of life. It is about recognizing women's work, paid or unpaid, as socially and economically valuable.

The attitude of a community towards the woman has a great social significance in Indian society. In traditional society, women were assigned a position subordinate to men. India is a male dominant society and traditionally jobs were meant for men. But as the international concern with gender relations in development has strengthened the affirmation that equality in the status of men and women is fundamental to every society, modern Indian Society has witnessed a gradual change in the status of women. Nowadays Economic independence was considered as one of the powerful routes to economic empowerment and thereby to gender equality. In modern Indian society women's participation in employment for their empowerment is widely identified. In this direction this research article has tried to trace the recent trends in the attitudes of Indians towards economic independence of the women.

\section{Statement of the Problem}

To understand the status of women in the Indian society, there is a necessity to trace the attitudes of its members towards women's economic independence. Therefore the present study made an effort to understand the recent trends in the attitudes of people towards economic independence of women of contemporary society.

\section{Objectives of the study}

The study has been taken up with following objectives-

1. To portray the opinions of people about necessity of economic independence for women,

2. To explore the level of changes took place in the economic status of women over the period of time,

3. To unveil the attitudes of the society towards women's economic independence

\section{Methodology:}

1. Universe of the study: The universe chosen for the present study is the western coastal strip region of Karnataka which is popularly known as Undivided Dakshina Kannada.

2. Sample Scheme: The researcher of the study, selected ' 250 ' households. The selection of the samples is done on the basis of 'Purposive multi-stage Sampling' in order to obtain a representative sample. The distribution of the sample from the universe of the study is as below-

Table: -1 Sample of the study (Age-wise Classification of Respondents)

\begin{tabular}{|c|c|c|c|c|c|}
\hline SI.No. & Age & M & $\mathbf{F}$ & Total & $\%$ \\
\hline 1 & $25-35$ & 24 & 12 & 36 & 14.40 \\
\hline 2 & $36-45$ & 51 & 14 & 65 & 26.00 \\
\hline 3 & $46-55$ & 72 & 4 & 76 & 30.40 \\
\hline 4 & $56-65$ & 45 & 4 & 49 & 19.60 \\
\hline 5 & 66-75 & 15 & 3 & 18 & 7.20 \\
\hline 6 & $76-85$ & 6 & 0 & 6 & 2.40 \\
\hline Total & & 213 & 37 & 250 & 100 \\
\hline
\end{tabular}

The table 1 exhibits that out of 250 households 85.2 percent of male respondents and 14.8 percent of female respondents were selected as samples for the present study. The age of majority respondents is between 
36 to 55 years. This age distribution of the respondents indicates that the proposed study had maximum data and views of young and middle- aged respondents and also some data from older persons.

\section{Tools of data collection}

The major techniques used for primary data collection are- participant, interview and questionnaire. Detailed description of the activities, attitudes and opinions of the women respondents was collected through Focused Group Discussion targeted to the problem of the research.

Secondary data was gathered from various sources such as Gazetteers, souvenirs of various caste-communities, magazines and community web sites etc.

\section{Importance of the Research:}

The present investigation is justifiable from the theoretical as well as practical point of view. As nowadays concept of women and development is being given more importance, at the present situation there is a necessity of study of economic empowerment of women. At the theoretical level the investigation will help to get some conceptual clarification such as status of women, economic independence, gender equality etc. At the practical level the present research-study would help in understanding the cumulative impact of a number of dependent and independent factors on changing trends of improvement in women economic status. The study is very helpful to understand the recent trends in the community attitudes towards economic empowerment of women and also trace out actual notions of people to women becoming economically independent and thereby establishing gender equality in the society.

\section{General Demographic Aspects of the area of the study:}

Undivided Dakshina Kannada is the universe of the present study. Before 1860, Dakshina Kannada was part of a greater district called Canara, which was under a single administration in the Madras Presidency. In 1860, the British split the area into South Canara and North Canara, the former being retained in the Madras Presidency, while the later was made a part of Bombay Province in 1862. Before 1997 Dakshina Kannada was vast district with eight Taluks. On August 1997, it was bifurcated into Dakshina Kannada (D.K.) and Udupi districts. As a socio- cultural region, undivided Dakshina Kannada district is inhabited by diverse castes and communities, speaking a variety of languages and observing a variety of customs and traditions. This region has also undergone drastic socio-cultural changes due to the spread of modern education, urbanization, economic development, demographic changes, and ideological inferences.

\section{Analysis of Data}

Attitudes about the superiority of men and inferiority of women at the household and family level are very common. In most of the caste-communities men were widely considered the 'head of the household' with superior status and decision-making authority and often greater rights and freedoms. Women's empowerment at the household and family level is crucial to their full participation in and contribution to all other spheres of society. The traditional Indian society was very much supportive to gender inequality and each caste restricted the freedom of women. But in modern India, a lot of changes have been taken place. This new trends in modern society has contributed a lot for the improvement in the status of women. The study analyzed the influence of changing attitudes of people and its role in improvement of economic independence of women in the present society as below-

\section{Economic Status of Women}

N. Jayaram (1987, p.90) states that inequality between man and woman and the sexual division of labour is found to be a fundamental phenomenon in many societies today- so much so that people in these societies even seem to believe that they are due to natural differences between the sexes. The present study has assessed the attitude of people towards economic independence of women by collecting data on opinions of sample- respondents about the level of economic status of women, which is as below - 
TABLE: 2- Opinion about the Economic status of Women.

\begin{tabular}{|c|c|c|}
\hline Sl. No. & Level of status & Total (\%) \\
\hline 1 & Superior to men & $\begin{array}{ll}5 & (2.00)\end{array}$ \\
\hline 2 & Equal to men & $179(71.60)$ \\
\hline 3 & Lower to men & $60 \quad(24.00)$ \\
\hline 4 & No comments & $\begin{array}{ll}06 & (2.4)\end{array}$ \\
\hline \multicolumn{2}{|c|}{ Total } & 250 \\
\hline
\end{tabular}

Source: Primary

Majority respondents [71.60\%] viewed that the economic status of women should be equal to men. Then out of the total sample, according to 24 percent of them, it must be inferior to men. Only $2.4 \%$ of them did not react. It is interesting to note that only $2 \%$ are in favor of superior economic status of women to men.

Thus the data of this table indicates that contemporary society is in favor of equal economic status of women to men. But even now many are not having favorable attitude towards it. Identifiable number of people still expects that the economic status women should be inferior to men and not superior to men.

\section{Necessity of Economic Independence of Women:}

At present the old notion that 'men for the field and women for the kitchen' is exploded. Modern employment opportunities had opened up new avenues for women to become economically independent. They have now become earning member of the family. Emancipation and empowerment of women is taking place through becoming economically independent. Therefore present study tried to verify the necessity of economic independence for women. To meet this purpose, the study traced the attitude of the community members towards it, which is shown in the following table-

TABLE: 3 -Attitude of the Community towards Economic Independence of women

\begin{tabular}{|c|c|c|c|}
\hline Sl.No. & Attitudes & Frequency & \% \\
\hline 1 & Needed & 125 & 50.00 \\
\hline 2 & No Need & 2 & 0.80 \\
\hline 3 & Most Necessary & 107 & 42.80 \\
\hline 4 & Not Necessary & 5 & 2.00 \\
\hline 5 & No Comments & 11 & 4.40 \\
\hline \multicolumn{2}{r|}{} & $\mathbf{2 5 0}$ & $\mathbf{1 0 0}$ \\
\hline
\end{tabular}

Source: Primary

It shows that out of ' 250 ' sample households. $50 \%$ felt that there is a need for women becoming economically independent and also other $42.80 \%$ stressed its necessity. A very few said that there is no necessity of it and some of them did not answer as they do not reveal their inner feeling. This means that a large number of households had a favorable attitude towards the acquiring of economic independence by the women. 


\section{Reasons for Necessity:}

The members of these ' 232 ' respondents, who supported the view of necessity of women becoming economically independent, tried to justify their attitude on the basis of different following grounds-

TABLE: 3.1 -Reasons for Necessity of Economic Independence for women

\begin{tabular}{|l|l|l|}
\hline \multicolumn{1}{|c|}{ Sl.No. } & \multicolumn{1}{|c|}{ Attitudes } & \multicolumn{1}{|c|}{ Frequency } \\
\hline \multirow{2}{*}{} & & \multicolumn{1}{|c|}{160} \\
\hline & To improve the economic and social status of the family & \\
\hline 2 & & 105 \\
\hline 3 & Access of good education for their children & \\
\hline 5 & To ascribe gender equality & 70 \\
\hline 6, & Reduces dependence on men & 20 \\
\hline & Self - pride and self confidence. & 15 \\
\hline & Other & 18 \\
\hline
\end{tabular}

Some of them found the necessity of economic independence of their women for more than one reasons.

\section{Reasons for unfavorable attitude for Economic Empowerment of women:}

TABLE: 3.2 -Reasons for No Necessity of Economic Independence for women

\begin{tabular}{|l|l|c|}
\hline \multicolumn{1}{|c|}{ Sl.No. } & \multicolumn{1}{|c|}{ Attitudes } & Frequency \\
\hline 1. & The status of the women should be limited to house & 4 \\
\hline 2. & Lose interest in upbringing of children & 7 \\
\hline 3. & Leads to marital- conflict & 7 \\
\hline 4. & Decline of husband's status in the family & 3 \\
\hline 5. & Leads to immorality & 5 \\
\hline 6. & All the above & \\
\hline
\end{tabular}

There are also a very few respondents who opined that there is no need and necessity of economic independence of women of its community. According to them, the status of women should be limited to home only as it creates some problems such as employment makes them to neglect their children; it will lead to decline of the husband's status, it increases immorality among women and also it leads to marital conflicts.

\section{Inheritance of Property:}

Kingsley Davis (1948, p.409) notes that ordinarily inheritance of the property is a kinship institution reflecting the dominant pattern of family organization in the society. In India, though legal system supports the equal share of the property between sons and daughters, still in some communities daughters were not given the legal share and after marriage, they were not considered as eligible for the inheritance of ancestral property. Therefore the present study attempted to explore the rule of inheritance of property prevalent in the community. The table below gives an account of the responses of the respondents about equal property rights in their family- 
TABLE: 4 -Responses on the equal property right given to daughter or sister of the family

\begin{tabular}{|l|l|l|l|}
\hline Yes & No & No response & Total \\
\hline $164(65.60)$ & $\begin{array}{l}45 \\
(18.00)\end{array}$ & $\begin{array}{l}41 \\
(16.40)\end{array}$ & 250 \\
\hline
\end{tabular}

As per the data in the table a large number of respondents of responded that property was divided equally between sons and daughters of their family. Only a small number of sample households did not give equal property right to the daughters of their family. Further $16.40 \%$ of them did not respond as the property of some not yet divided and some do not have any property.

\section{Opinion about Employment of women:}

This research study collected data about the opinion of people regarding working of women of their family in far-off cities. So on the basis of this data, it is clear that even though they had favorable attitude towards women's employment, majority of them are not ready to send their female members of their family to faraway place for employment.

\section{Economic freedom of Women:}

The present article tried to understand the attitudes of the community as a whole towards Economic freedom their women, the data about which has revealed in the table below:-

TABLE:6 - Attitude of the community towards the economic freedom of Women.

\begin{tabular}{|l|l|l|}
\hline \multicolumn{1}{|c|}{ Category } & \multicolumn{1}{|c|}{ Frequency } & \multicolumn{1}{c|}{$\%$} \\
\hline Yes & 181 & 72.4 \\
\hline No & 69 & 27.6 \\
\hline Total & $\mathbf{2 5 0}$ & $\mathbf{1 0 0}$ \\
\hline
\end{tabular}

Majority respondents expressed their opinion that their community is not against the economic freedom of women. But, some of them were not supporting the notion of giving freedom for women in spending money and ownership of property.

\section{Spending their Salary:}

Another interesting thing traced in the present study is about spending of salary by working women. The study intended to explore whether really there is support for the economic independence of their women. The present study focused on this point because it is said that in the patriarchal traditional societies like India, sex role expectations favor male dominance in the family and though women contribute to their family income, men only regarded as a provider and main earners. The opinion about the spending of the salary by working women, as prescribed by the respondents of the study is revealed in the table:- 
TABLE: 8 --Opinion on Spending of Salary by working Women

\begin{tabular}{|l|l|l|}
\hline Sl. No. & Opinion & Total \\
\hline 1 & Giving to the male members & 30 \\
\hline 2 & Family Expenditure & 185 \\
\hline 3 & Keep for themselves & 32 \\
\hline 4 & Spend for Luxuries & 14 \\
\hline
\end{tabular}

Source of data: Primary

185 respondents of the study opined that female members must spent their salary completely to meet the family expenditure; further members of ' 30 ' said that $\mathrm{r}$ working women must give the salary to their fathers or husbands or to any male member of the family. Only ' 32 ' households said that their working women can keep for their personal use and members of '14' said that female members of their family may spend their salary to their wish.

These opinions of the respondents of study indicate that though community favored the employment of its women, it did not give economic independence for them. Women were taken as a contributor for family income and they were not given the freedom to spend the money, which they earn for themselves.

\section{Findings}

\section{The important findings of this study is as below-}

1. Contemporary society is in favor of equal economic status of women to men. But even now most is not having favorable attitude towards it. Identifiable number of people still expects that the economic status women should be inferior to men and not superior to men.

2. Modern employment opportunities had opened up new avenues for women to become economically independent. They have now become earning member of the family. Emancipation and empowerment of women is taking place through becoming economically independent

3. Nowadays the society had a favorable attitude towards the acquiring of economic independence by the women.

4. Economic independence of women is supported for main reason that will help for improve the economic status of the families and education of their children,

5. Supportive reasons for economic independence of women are to institute gender equality, reduction of dependency on men and instill self-pride and self confidence among women.

6. There is also disapproval for economic independence of women, due to fear of decline of male domination and misuse of freedom by women, marital- conflict etc.

7. Most of the people are in favor of equal property right given to daughter or sister of the family.

8. Though community favored the employment of its women, it did not give economic independence for them in a real sense. Women were taken as a contributor for family income and they were not given the freedom to spend the money, which they earn for themselves. Sex role expectations favour male dominance in the family and though women contribute to their family income, men only regarded as a provider and main earners.

\section{Conclusion:}

In this way the changing attitudes of the community is very much contributed for the improvement and empowerment of women in Indian society. But while increasing numbers of people are replacing these notions of family hierarchies with notions of equality, there is still a long way to go. There is very much necessity of 
providing gender-sensitive training for women and men to promote non-discriminatory working relationships and respect for diversity in family, work and community as a whole. In this way this paper concludes that to make use of the provision of equality ensured by constitution and to empower themselves there is a necessity of participation of women in economic activities and making use of modern occupational opportunities. In the male dominated society where women treated as weaker section of the society there is a need of a job reservation for emancipation and empowerment of women. Most cases the male dominated Indian society normally do not accept directly the contribution of female members to its family income. The occupational status of the women positively contributed to the enhancement of her prestige and power in the family.

\section{References:}

[1]. Bhat, Gururaj P: Studies in Tuluva History and Culture, Manipal Power Press, Udupi, 1975.

[2]. Bose, N.K: Culture and Society in India, Asia Pub. House, Bombay, 1967.

[3]. Chapman, Jane Roberts(Ed.): Economic Independence for Women: The Foundation for Equal Rights, Sage Publications, 1976

[4]. Dalton, George (ed.): Economic Development and Social Change, Natural History Press, New York, 1971.

[5]. Davis, Kingsley: Human Society, the Macmillan Company, New York, 1965.

[6]. Desai, A.R: Social Background of Indian Nationalism, Popular Prakashan, Bombay, (1948) 1976.

[7]. Epstein, Scarlett, T: South India : Yesterday, Today and Tomorrow, The Macmillan press, Loudon, 1973.

[8]. Hate, Chandrakala. A: Changing Status of Women, Allied Publishers, Bombay, 1969.

[9]. Jayaram N: Introductory Sociology, Macmillan India Ltd., Madras, 1987.

[10].Kamath Suryanath U. (ed.): Karnataka State Gazetteer, part-I, Govt. of Karnataka, Bangalore, 1982.

[11].Kapadia, K.M: Marriage and Family in India, Oxford University press, Bombay, 1958.

[12].Kudva, K.K: Dakshina Kannada Ithihasa, Karkala, 1948.

[13].Kuppuswamy, B: Social Change in India, Vikas Publishing House, New Delhi, 1972.

[14].Prabhu, P.H: Hindu Social Organization, Popular Prakashan, Bombay, 1940. 